\title{
Greenhouse Screening of Citrus Rootstock for Tolerance to Bicarbonate-induced Iron Chlorosis
}

\author{
Sudahono ${ }^{1}$, D.H. Byrne, and R.E. Rouse ${ }^{2}$ \\ Department of Horticultural Sciences, Texas A\&M University, College Station, \\ TX 77843-2133
}

Additional index words. bicarbonate, lime-induced chlorosis, potassium carbonate, sand culture, citrumelo, citrange, Citrus aurantium, C. grandis, C. jambhiri, C. limon, C. limonia, C. paradisi, C. reticulate, C. sinensis, Poncirus trifoliata

Abstract. Eighteen citrus rootstock seedling lines were tested for their tolerance to $\mathrm{Fe}$ chlorosis using sand culture. Potassium carbonate was used to induce Fe-deficiency chlorosis. Chlorosis was quantified by 1) visual ratings, 2) SPAD-502 chlorophyll meter readings, 3) leaf chlorophyll concentration, 4) leaf active $\mathrm{Fe}$, and 5) leaf total $\mathrm{Fe}$. The first four criteria were well correlated among each other but not with leaf total Fe. Although any of the first four measurements could be used to quantify chlorosis, visual ratings and SPAD-502 readings were more convenient. The rootstock that have been reported to be tolerant or very susceptible to $\mathrm{Fe}$ chlorosis in calcareous soils were rated similarly for tolerance to bicarbonate-induced Fe chlorosis. Nontrifoliate types such as Texas sour orange (C. aurantium L.), Cleopatra mandarin (C. reticulata Blanco), Vangasay lemon $(C$. limon Burro.), and Ridge pineapple $\mathrm{x}$ Milam 1578-201 (C. sinensis L. Osbeck x C. jambhiri) were tolerant to moderately tolerant. Although most of the trifoliate hybrids tested were moderately susceptible to very susceptible, Smooth Seville $x$ Argentine trifoliate $\{[C$. grands (L.) Osbeck x C. aurantium] x Poncirus trifoliata (L.) Raf.\} and F-81-12 citrange (C. sinensis $\mathrm{x} P$. trifoliata) exhibited relatively high tolerance to lime-induced Fe chlorosis.

About $25 \%$ to $30 \%$ of the earth's land surface is calcareous, and many plants, including citrus, growing in these soils develop $\mathrm{Fe}$ deficiency (Wallace and Lunt, 1960; Vose, 1982). Although Fe chelate applications can alleviate this problem, they are expensive. Rootstock tolerant to Fe deficiency in calcareous soils are used frequently, and they are a less expensive alternative, Citrus rootstock vary in their tolerance to lime-induced $\mathrm{Fe}$ chlorosis (Hamze et al., 1986), from trifoliate orange [Poncirus trifoliata (L.) Raf.] (susceptible) to the more tolerant citrus types such as sour orange, various mandarins $(C$. reticulate Blanco, C. nobilis Lour., and $C$. depressa Hay), limes (C. limonia Osbeck), and lemons (C. jambhiri Tan). Sweet orange (C. sinensis L. Osbeck) and trifoliate hybrids such as citranges and citrumelos have intermediate to low tolerance (Cooper and Peynado, 1954; Hamze and Nimah, 1982; Hamze et al., 1986).

Sour orange is a widely used commercial rootstock because it is tolerant to salinity, soilborne diseases, cold weather, waterlog, and soils that are calcareous and high in clay con-

Received for publication 6 Feb. 1993. Accepted for publication 6 Aug. 1993. The cost of publishing this paper was defrayed in part by the payment of page charges. Under postal regulations, this paper therefore must be hereby marked advertisement solely to indicate this fact.

'Current address: Fakultas Pertanian, Universitas Jambi, J1 Sri Sodewi-Telanaipura, Jambi, 36122, Indonesia.

${ }^{2}$ Current address: Southwest Florida Research and Education Center, P.O. Drawer 5127, Immokalee, FL 33934. tent. Trees on sour orange produce high-quality fruit but yield less than trees on various trifoliate hybrids, such as 'Swingle' citrumelo, Troyer citrange, Morton citrange, and Rangpur $\times$ Troyer (Rouse et al., 1986; Wutscher, 1979). The use of sour orange is limited to areas not

Table 1. Citrus rootstocks screened for tolerance to bicarbonate-induced chlorosis.

\begin{tabular}{|c|c|}
\hline Common name & Binomial \\
\hline \multicolumn{2}{|l|}{ Nontrifoliate } \\
\hline Texas sour orange & Citrus aurantium $\mathrm{L}$. \\
\hline Cleopatra mandarin & C. reticulata Blanco \\
\hline Vangasay lemon & C. limon Burm. \\
\hline Ridge pineapple x Milam (1578-201) & C. sinensis L. Osbeck $\times$ C. jambhiri \\
\hline \multicolumn{2}{|l|}{ Trifoliate orange } \\
\hline Flying Dragon trifoliate & Poncirus trifoliata (L.) Raf. \\
\hline \multicolumn{2}{|l|}{ Trifoliate hybrid } \\
\hline \multicolumn{2}{|l|}{ Citrumelo } \\
\hline F-80-3 & P. trifoliata $\times$ C. paradisi Macf. \\
\hline F- $-80-5$ & P. trifoliata $\times$ C. paradisi Macf. \\
\hline F-80-8 & P. trifoliata $\times$ C. paradisi Macf. \\
\hline F-80-18 & P. trifoliata $\times C$. paradisi Macf. \\
\hline \multicolumn{2}{|r|}{ (1) } \\
\hline Troyer & C. sinensis $\times P$. trifoliata \\
\hline Benton & C. sinensis $\times P$. trifoliata \\
\hline F-81-12 & C. sinensis $\times$ P. trifoliata \\
\hline Trifoliate $x$ Ridge pineapple (1573-26) & P. trifoliata $\times$ C. sinensis \\
\hline \multicolumn{2}{|l|}{ Other } \\
\hline \multicolumn{2}{|l|}{ Cleopatra mandarin $\mathrm{x}$} \\
\hline Flying Dragon trifoliate & C. reticulata $\times P$. trifoliata \\
\hline Sunki mandarin $\mathrm{x}$ Benecke trifoliate & C. reticulata $\times P$. trifoliata \\
\hline Rangpur lime $\times$ Swingle trifoliate & C. limonia Osbeck $\times$ P. trifoliata \\
\hline Smooth Seville $x$ Swingle trifoliate & $\begin{array}{l}\text { [C. grandis (L.) Osbeck } \mathrm{x} \\
\text { C. aurantium }] \times \text { P. trifoliata }\end{array}$ \\
\hline Smooth Seville $x$ Argentine trifoliate & $\begin{array}{l}\text { [C. grandis (L.) Osbeck } \mathrm{x} \\
\text { C. aurantium] } \times \text { P. trifoliata }\end{array}$ \\
\hline
\end{tabular}

${ }^{2}$ All seed was obtained from the Division of Plant Industry, Bureau of Citrus Budwood Registration, Winter Haven, Fla., except for the Texas sour orange, which was obtained from the Texas A\&I Citrus Center, Weslaco. relative leaf chlorophyll content (Marquard invaded yet by citrus tristeza virus (CTV) and its insect vector. Some regions, such as the Lower Rio Grande Valley of Texas, are threatened as this viral problem spreads northward from Mexico (Davis, 1986; Rouse et al., 1986; Wutscher, 1979). Alternate rootstock tolerant to calcareous soils and CTV are needed.

Bicarbonate has been cited as a major causal factor of $\mathrm{Fe}$ chlorosis in calcareous soils and in solution culture systems (Chancy et al., 1989). Thus, bicarbonate has been used successfully in nutrient solutions to mimic the effects of calcareous soils. Good correlations between the tolerance rankings of nutrient solution and field tests (Coulombe et al., 1984; Dragonuk et al., 1989) have been reported.

The intensity of leaf $\mathrm{Fe}$ chlorosis is usually rated subjectively by visual scoring (Byrne, 1988; Coulombe et al., 19-84; Hamze et al.. 1986; Maxwell and Wutscher, 1976) and, less commonly, by the leaf concentrations of $\mathrm{Fe}$ and chlorophyll. Although total Fe concentrations of chlorotic leaves are not consistently correlated with leaf chlorosis (Abadia et al., 1985; Pierson and Clark, 1984; Rao et al., 1987; Rashid et al., 1990), acid-soluble (active) $\mathrm{Fe}$ is consistently correlated with leaf chlorophyll concentration in a variety of plants (Takkar and Kaur, 1984). Leaf chlorophyll concentration is measured by extraction and quantification via spectrophotometry (Hiscox and Israelstam, 1979), with reflectometers that measure leaf greenness (Singha and Townsend, 1989), or with portable chlorophyll meters (MinoltaCameraCo., Japan) that calculate the and Tipton, 1987; Yadava, 1986).

The objectives of this study were to evaluate the usefulness of several chlorosis measurements and to determine the tolerance of 
various CTV-tolerant rootstock to bicarbonate-induced $\mathrm{Fe}$ chlorosis under greenhouse conditions.

\section{Materials and Methods}

Seven-week-old seedlings of 18 citrus rootstock (Table 1) were planted and grown in individual plastic pots (with $\approx 0.5$ liter of washed sand) in a greenhouse. During the 3week establishment period, the plants were watered with a half-strength macronutrient and full-strength micronutrient Hoagland's solution (Hoagland and Arnon, 1938) adjusted to $\mathrm{pH} 6.0$ with $1.0 \mathrm{~N} \mathrm{NaOH}$. Iron (18 ppm) was added in the form of FeEDTA.

After the establishment period, the plants were arranged in a randomized complete-block design with 10 replications and three $\mathrm{pH} /$ bicarbonate treatments. The basic nutrient solution was modified by adding either $0,0.068$, or $0.148 \mathrm{~g}$ of $\mathrm{K}_{2} \mathrm{CO}_{3}$ /liter of solution. The respective $\mathrm{pH}$ and bicarbonate levels (in millimolar) were $6.00,0.16 ; 7.5,4.00$; and 8.5, 6.00. During the first 5 weeks of treatment, a minimum of $50 \mathrm{ml}$ of nutrient solution was added twice a week; from week 6 until week $15,100 \mathrm{ml}$ was added twice a week. During this period, the mean air maximum and minimum temperature were 30 and $20 \mathrm{C}$, respectively.

Chlorosis was measured on the youngest fully developed leaves with the SPAD-502 chlorophyll meter (Minolta) and by visual chlorosis ratings after 15 weeks of treatment. The chlorosis scale was as follows: $1=$ healthy green leaves; 2 = yellowish-green interveinal areas, green veins; $3=$ greenish-yellow interveinal areas, green veins; $4=$ yellow interveinal areas, green veins; $5=$ yellowwhite interveinal areas, pale-green veins. In addition, leaves (the three youngest topmost fully expanded leaves) from three one-plant samples pooled over replications ( $1-3,4-6$, and 7-10) were collected for an analysis of chlorophyll, active-Fe, and total Fe concentration. For chlorophyll measurement, 100-mg leaf samples were extracted with dimethyl sulfoxide (Hiscox and Israelstam, 1979) and quantified spectrophotometrically at 645 and 663 nm (Bruinsma, 1963). Active Fe (acidsoluble $\mathrm{Fe}$ ) was determined using the method described by Takkar and Kaur (1984) and Katyal and Sharma (1980), and total Fe, P, K, $\mathrm{Ca}, \mathrm{Mg}, \mathrm{Mn}$, and $\mathrm{Zn}$ were determined on leaf samples that were washed (Smith and Storey, 1976), dried, ground, and digested (Gallaher et al., 1975). The digested samples were quantified with an Applied Research Labs inductively coupled plasma atomic spectrophotometer (model 3510; Sunland, Calif.). The nutrient solutions were also quantified for the previously listed elements.

The chlorosis measurements were subjected to correlation analysis. The bicarbonate $x$ rootstock factorial was tested with analysis of variance. The $\mathrm{pH} 6.0$ treatment mean within a rootstock was separated from other treatment means by orthogonal contrasts. The citrus rootstock were placed into tolerance categories with respect to their performance relative to three standard rootstock: Texas sour orange (tolerant), Troyer citrange (moderate), and Flying Dragon trifoliate (very susceptible). Each rootstock was compared to all other rootstock in the trial with paired contrasts $(\alpha \leq 0.05)$. If the rootstock was not distinguishable from Texas Sour orange, Troyer citrange, or Flying Dragon trifoliate, it was rated 1,3 , or 5 , respectively. Two and 4 were used for the intermediate categories. If a given rootstock fell into two categories, the average score was used.

\section{Results and Discussion}

Nutrient concentrations in solutions and tissue. Adding $\mathrm{K}_{2} \mathrm{CO}_{3}$ to the basic nutrient solutions raised the solution concentration of $\mathrm{K}$ but lowered $\mathrm{P}, \mathrm{S}, \mathrm{Ca}, \mathrm{Mg}, \mathrm{Mn}$, and $\mathrm{Zn}$ concentrations. The Fe concentration remained stable because of the chelated form used (Table 2 ). The most marked decreases in solution nutrient concentration from $\mathrm{pH} 6.0$ to $\mathrm{pH} 8.5$ on a percent basis was for $\mathrm{P}(-71 \%), \mathrm{Mn}$ $(-85 \%)$, and $\mathrm{Zn}(-88 \%)$. Although this same trend was apparent in the tissue nutrient concentrations, changes were generally not as extreme (Table 2). Despite these trends, only active-Fe tissue concentration was well correlated with chlorosis. Although Mg was significantly correlated with chlorosis, the correlation was weak (Table 2), and no Mg deficiency symptoms were apparent during the experiment. The only recognizable nutrient deficiency symptom was Fe deficiency, which was alleviated when Fe chelate was applied.

Chlorosis indicators. All chlorosis indicators, except total Fe concentration of the leaves, were correlated with each other (Table 3). Total Fe concentration is not correlated with leaf chlorophyll concentration or chlorosis in several crops (Abadia et al., 1985; Rao et al., 1987; this study); thus, it is not useful for measuring leaf chlorosis. This noncorrelation led Chancy (1984) to define chlorosis due to Fe deficiency as any leaf chlorosis that regreens when FeEDDHA or $\mathrm{FeSO}_{4}$ (not when other nutrients) are" applied. Active Fe and chlorophyll were highly correlated with each other and with SPAD readings. The correlations between chlorophyll and active-Fe concentrations with the chlorosis ratings were weaker (Table 3). This relationship indicates that the SPAD chlorophyll meter readings are better indicators of leaf chlorophyll and active-Fe concentrations than are chlorosis ratings.

SPAD readings are influenced by leaf condition (Campbell et al., 1990). Thus, although leaf SPAD meter offers an. easy means of measuring leaf chlorophyll, the values collected are relative, and a standard curve must be constructed for each experiment if absolute values are required. The accuracy of leaf chlorosis ratings is limited by the precision of the chlorosis scale and the experience of the researcher. Nevertheless, when dealing with large plants, chlorosis ratings are more efficient than SPAD readings and generally summarize the condition of new growth. In contrast, SPAD readings attempt to characterize plant condition by subsampling smaller regions.

All the evaluation attributes that were correlated with leaf chlorosis showed a significant rootstock $\times \mathrm{pH} /$ bicarbonate interaction (Table 4). This result indicates that the rootstock showed unequal development of bicarbonate-induced chlorosis in response to increasing bicarbonate concentration. Thus, rootstock possess different tolerance levels to this type of stress. Most rootstock had more leaf

Table 2. Nutrient concentration of nutrient solutions and corresponding plant tissue, and the correlation of nutrient concentration of tissue with leaf chlorosis

\begin{tabular}{|c|c|c|c|c|c|c|c|}
\hline \multirow[b]{2}{*}{ Element } & \multicolumn{3}{|c|}{ Solution concn $(\mu \mathrm{M})^{z}$} & \multicolumn{3}{|c|}{ Tissue concn $(\mu \mathrm{M})^{\mathrm{z}}$} & \multirow{2}{*}{$\begin{array}{c}\text { Correlation } \\
\text { with } \\
\text { chlorosis }^{y} \\
\end{array}$} \\
\hline & 6.0 & 7.5 & 8.5 & 6.0 & 7.5 & 8.5 & \\
\hline $\mathrm{P}$ & 720 & $440^{*}$ & $210^{*}$ & 9.7 & 8.4 & 8.7 & NS \\
\hline K & 3820 & $4320^{*}$ & $5480^{*}$ & 87 & $110^{*}$ & $121^{*}$ & NS \\
\hline$S$ & 1190 & $1020^{*}$ & 1080 & --- & --- & --- & --- \\
\hline $\mathrm{Ca}$ & 3340 & $2740^{*}$ & $2300^{*}$ & 31.7 & $25.9^{*}$ & $21.2^{*}$ & NS \\
\hline $\mathrm{Mg}$ & 1380 & $1110^{*}$ & $1130^{*}$ & 7 & $5.8^{*}$ & $4.5^{*}$ & $-0.4^{* *}$ \\
\hline $\mathrm{Fe}$ & 17 & 16.6 & 15.8 & 1850 & 1750 & 1790 & NS \\
\hline Active $\mathrm{Fe}$ & --- & --- & --- & 344 & $299^{*}$ & $254^{*}$ & $-0.7^{* * *}$ \\
\hline $\mathrm{Mn}$ & 13.1 & $6.6^{*}$ & $2.0^{*}$ & 894 & $795^{*}$ & $692^{*}$ & NS \\
\hline $\mathrm{Zn}$ & 4.3 & $1.1^{*}$ & $0.5^{*}$ & 421 & $307^{*}$ & 374 & NS \\
\hline
\end{tabular}

${ }^{2}$ Contrast comparing modified solutions to basic half-strength Hoaglands solution.

${ }^{y}$ Correlation between chlorosis ratings and tissue nutrient concentration $(n=54)$.

Ns, $* * * * * *$ Nonsignificant or significant at $\mathrm{F}^{\prime}<0.05,0.01$, or 0.001 , respectively.

Table 3. Correlations among chlorosis indicators and foliar active-Fe concentration,

\begin{tabular}{lcccr}
\hline \hline & \multicolumn{3}{c}{ Chlorosis indicators } \\
\cline { 2 - 5 } Variable & Chlorophyll & Chlorosis & SPAD-502 & Total \\
rating & reading & Fe \\
\hline Active Fe & $0.87^{* * *}$ & $0.71^{* * *}$ & $0.86^{* * *}$ & -0.23 \\
Chlorophyll & --- & $-0.69^{* * *}$ & $0.94^{* * *}$ & -0.15 \\
Chlorosis rating &.-- & --- & $0.80^{* * *}$ & 0.08 \\
SPAD-502 & --- & -- & --.13 \\
\hline
\end{tabular}

"Chlorosis rating scale: 1 = healthy green leaves; 3 = greenish-yellow interveinal areas, green veins; $5=$ yellow-white interveinal areas, pale-green veins.

$* * *$ Significantly different from zero at $P \leq 0.001 ; \mathrm{n}=54$ 
Table 4. Leaf chlorosis ratings, chlorophyll concentration, foliar active Fe, and ASPAD-502 readings of citrus rootstock seedlings grown in sand culture at three pH/ bicarbonate levels.

\begin{tabular}{|c|c|c|c|c|c|c|c|c|c|c|c|c|}
\hline \multirow[b]{3}{*}{ Rootstock } & \multicolumn{3}{|c|}{$\begin{array}{c}\text { Leaf } \\
\text { chlorosis } \\
\text { ratings }^{\mathrm{z}}\end{array}$} & \multicolumn{3}{|c|}{ 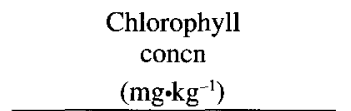 } & \multicolumn{3}{|c|}{$\begin{array}{c}\text { Active Fe } \\
\text { concn } \\
(\mu \mathrm{M})\end{array}$} & \multicolumn{3}{|c|}{$\begin{array}{c}\text { SPAD-502 } \\
\text { reading }\end{array}$} \\
\hline & & & & & & $\mathrm{pH}^{y}$ & & & & & & \\
\hline & 6.0 & 7.5 & 8.5 & 6.0 & 7.5 & 8.5 & 6.0 & 7.5 & 8.5 & 6.0 & 7.5 & 8.5 \\
\hline \multicolumn{13}{|l|}{ Nontrifoliates } \\
\hline Texas sour orange & 1.0 & 1.2 & 1.0 & 2667 & 2621 & $2307^{* *}$ & 663 & 663 & 645 & 65 & 65 & 63 \\
\hline Cleopatra mandarin & 1.0 & 1.0 & 1.0 & 1692 & $1267^{* *}$ & $683^{* *}$ & 609 & 609 & $448^{* *}$ & 57 & $48^{* *}$ & $31^{* *}$ \\
\hline Vangasay lemon & 1.1 & 1.3 & 1.4 & 1466 & $1435^{*}$ & $1400^{* *}$ & 466 & $358^{* x}$ & $286^{2 *}$ & 53 & 53 & $52^{* *}$ \\
\hline \multicolumn{13}{|l|}{ Ridge pineapple $x$} \\
\hline Milam (1578-201) & 1.0 & 1.2 & 1.5 & 1379 & 1371 & $1301^{* *}$ & 394 & $340^{* *}$ & $269^{* *}$ & 51 & 50 & $48^{* *}$ \\
\hline \multicolumn{13}{|l|}{ Trifoliate hybrids } \\
\hline \multicolumn{13}{|l|}{ Citrumelo } \\
\hline F-80-3 & 1.3 & 1.4 & 1.7 & 1300 & $927^{*}$ & $553^{* *}$ & 340 & 286 & 251 & 48 & $39^{* *}$ & $25^{* *}$ \\
\hline F-80-5 & 1.2 & $2.2^{*}$ & $2.2^{*}$ & 967 & 944 & $927^{*}$ & 251 & 215 & 179 & 41 & 40 & $39^{* *}$ \\
\hline F-80-8 & 2.0 & 2.4 & $3.8^{*}$ & 841 & $793^{* *}$ & $648^{* *}$ & 215 & 179 & $143^{* *}$ & 37 & $35^{* *}$ & $30^{* *}$ \\
\hline F- $80-18$ & 2.6 & $3.3^{*}$ & $3.8^{*}$ & 589 & $485^{* *}$ & $417^{* *}$ & 161 & 161 & 143 & 25 & $20^{* *}$ & $16^{* *}$ \\
\hline \multicolumn{13}{|l|}{ Citrange } \\
\hline Troyer citrange & 1.0 & 1.4 & $1.6^{*}$ & 1340 & 1324 & 1361 & 340 & 304 & $269^{*+}$ & 50 & 49 & 50 \\
\hline Benton citrange & 1.2 & 1.6 & $1.8^{*}$ & 1198 & $1141^{* *}$ & $1109^{* *}$ & 322 & $286^{* *}$ & $215^{* *}$ & 47 & 46 & $45^{*}$ \\
\hline F-81-12 citrange & 1.0 & 1.3 & 1.4 & 1570 & $1514^{* *}$ & $1488^{* *}$ & 519 & $376^{* *}$ & $304^{* *}$ & 55 & 55 & $54^{* *}$ \\
\hline \multicolumn{13}{|l|}{ Trifoliate $\mathrm{x}$} \\
\hline Ridge pineapple (1573-26) & 1.1 & 1.5 & $2.7^{*}$ & 811 & $756^{*}$ & $515^{* *}$ & 197 & 161 & $143^{* *}$ & 32 & $31^{*}$ & $23^{* *}$ \\
\hline \multicolumn{13}{|l|}{ Other } \\
\hline \multicolumn{13}{|l|}{ Cleopatra $x$} \\
\hline Flying Dragon trifoliate & 2.0 & 2.2 & 2.6 & 728 & $674^{*}$ & 703 & 179 & 161 & 143 & 32 & $31^{*}$ & 33 \\
\hline \multicolumn{13}{|l|}{ Sunki mandarin $\mathrm{x}$} \\
\hline Benecke trifoliate & 1.5 & 2.3 & $2.5^{*}$ & 904 & 883 & $868^{* *}$ & $233^{* *}$ & $197^{* *}$ & $161^{* *}$ & 39 & 38 & $37^{* *}$ \\
\hline \multicolumn{13}{|l|}{ Rangpur $x$} \\
\hline Swingle trifoliate & 1.2 & $1.9^{*}$ & 1.9 & 1050 & 1011 & $998^{* *}$ & 286 & $233^{*}$ & $197^{* *}$ & 44 & $42^{*}$ & $41^{*}$ \\
\hline \multicolumn{13}{|l|}{ Smooth Seville x } \\
\hline Swingle trifoliate & 1.1 & $1.9^{*}$ & $1.9^{*}$ & 1095 & 1085 & $1063^{* *}$ & 304 & $233^{* *}$ & $215^{* *}$ & 46 & 45 & $44^{* *}$ \\
\hline \multicolumn{13}{|l|}{ Smooth Seville $x$} \\
\hline Argentine trifoliate & 1.1 & 1.1 & 1.3 & 1721 & $1660^{*}$ & $1681^{* *}$ & 555 & $501^{* *}$ & $430^{* *}$ & 59 & $58^{*}$ & $57^{* *}$ \\
\hline \multicolumn{13}{|l|}{ Trifoliate orange } \\
\hline Flying Dragon & 2.5 & 2.7 & $4.1^{*}$ & 629 & $418^{* *}$ & $297^{* *}$ & 161 & 145 & $125^{*}$ & 28 & $16^{* *}$ & $15^{* *}$ \\
\hline Mean & 1.4 & $1.8^{* *}$ & $2.1^{* *}$ & 1218 & $1128^{* *}$ & $1029^{* *}$ & 342 & $299^{* *}$ & $254^{* *}$ & 45 & $42^{* *}$ & $40^{* *}$ \\
\hline
\end{tabular}

${ }^{2}$ Chlorosis rating scale: $1=$ healthy green leaves; 3 = greenish-yellow interveinal areas, green veins; $5=$ yellow-white interveinal areas, pale-green veins.

${ }^{y}$ Means for higher $\mathrm{pH}$ levels separated from $\mathrm{pH} 6.0$ with orthogonal contrasts; observations per mean with rootstock: leaf chlorosis rating = 10; chlorophyll, active $\mathrm{Fe}$, and SPAD-502 $=3$.

**,*Significant at $P £ 0.01$ or 0.05 , respectively. The interaction effect is significant at $P £ 0.07,0.001,0.001$, or 0.001 for chlorosis ratings, chlorophyll concentration, active $\mathrm{Fe}$, and SPAD-502 readings, respectively.

chlorosis, less chlorophyll, less active Fe, and lower SPAD-502 chlorophyll meter readings at $\mathrm{pH}$ 8.5. than at $\mathrm{pH}$ 6.0. The most tolerant rootstock (e.g., Texas sour orange) showed little change in chlorosis, active-Fe concentration, chlorophyll concentration, and SPAD502 readings as the $\mathrm{pH} /$ bicarbonate level increased from $\mathrm{pH} 6.0$ to $\mathrm{pH} 8.5$ (Table 4). In contrast, for the most susceptible rootstock (e.g., Flying Dragon), the level of all the chlorosis indicators decreased with increasing $\mathrm{pH} /$ bicarbonate levels. Although all plants were green at the beginning of the treatment, after 15 weeks five of the rootstock (F-80-8, F-8018, Cleopatra $x$ Flying Dragon, Sunki mandarin $\mathrm{x}$ Benecke, and Flying Dragon) showed chlorosis ratings $\geq 1.5$ at the lowest $\mathrm{pH} /$ bicarbonate treatment. These rootstock generally had low chlorophyll concentrations $(<910$ $\left.\mathrm{mg} \bullet \mathrm{kg}^{-1}\right)$, active-Fe concentrations $(<233 \mu \mathrm{m})$, and SPAD-502 readings $(<39)$. Although Trifoliate $\mathrm{x}$ Ridge pineapple ( 1573-26) rootstock did not exhibit appreciable leaf chlorosis, its chlorophyll content, active-Fe concentration, and SPAD-502 reading were low. The nutrient-solution concentration Fe level of $18 \mu \mathrm{M}$ was insufficient to maintain healthy green growth characteristics of these genotypes, suggesting their intolerance to low Fe levels.
Texas sour orange, a rootstock tolerant to calcareous soils, possessed the highest levels of chlorophyll, active Fe, and SPAD-502 readings. In contrast, Flying Dragon trifoliate, a rootstock susceptible to calcareous soils, had the lowest chlorophyll levels (Table 4). The trifoliate hybrids (citrumelos, citranges, and other hybrids) generally exhibited intermediate values for chlorosis, chlorophyll, active $\mathrm{Fe}$, and SPAD-502 readings. The trifoliate hybrids that possessed the highest levels of chlorophyll, active Fe, and SPAD-502 readings were Smooth Seville x Argentine trifoliate and F-81-12 citrange, whereas F-80-18 citrumelo had the lowest values for these variables (Table 4).

Critical active-Fe tissue concentrations. Foliar active-Fe concentrations of the rootstock ranged from 125 to $663 \mu \mathrm{M}$ on a fresh-weight basis (Table 4). Because the chlorosis symptoms were caused by Fe deficiency, the critical tissue concentrations for the development of $\mathrm{Fe}$ chlorosis can be established by comparing chlorosis symptoms with active$\mathrm{Fe}$ concentrations (Table 4). In the chlorotic plants (ratings $\geq 2$ ), the active-Fe levels ranged from 125 to $215 \mu \mathrm{M}$ with a mean of $161 \mu \mathrm{M}$; most of these plants were $<179 \mu \mathrm{M}$, which was designated as the deficiency level. The plants with marginal chlorosis (rating of 21.5 and <2.0) had active-Fe levels ranging from 161 to $269 \mu \mathrm{M}$ with a mean of $233 \mu \mathrm{M}$. Only one was $<179 \mu \mathrm{m}$. The low active-Fe levels ranged from 197 to $269 \mu \mathrm{M}$. Above this value, Fe is sufficient for normal growth and development. Among the plants that were not chlorotic (rating <1.5), there was a wide range (197-663 $\mu \mathrm{M})$ of active-Fe content; however, in all but two instances (F-80-5 and 1573-26), the active-Fe content was $2286 \mu \mathrm{M}$.

Relative chlorosis tolerance of 18 citrus rootstock. Relative rootstock tolerance to bicarbonate-induced chlorosis was assessed using the plant performance at the high $\mathrm{pH}$ (8.5)/ bicarbonate level because it best resembled the $\mathrm{pH}$ and bicarbonate levels in the calcareous soils ( $\mathrm{pH} 7.8$ to 8.5 ; bicarbonate 4.5 to 5.5 $\mu \mathrm{M})$ found in the citrus-growing area of the Lower Rio Grande Valley. Although the ranking with chlorosis ratings clearly distinguished between extreme responses, the top 10 ranked rootstock were not different from either Texas sour orange or Troyer citrange (Table 5). Thus, all were ranked as 2 . The three other chlorosis indicators (active $\mathrm{Fe}$, chlorophyll, and SPAD readings) were consistent in their rankings except for Cleopatra mandarin. The reason for the inconsistent responses of Cleopatra man- 
Table 5. Relative tolerance to bicarbonate-induced chlorosis for 18 citrus rootstock grown in greenhouse sand culture at $\mathrm{pH} 8.5 .^{2}$

\begin{tabular}{|c|c|c|c|c|}
\hline \multirow[b]{3}{*}{ Rootstock } & \multicolumn{3}{|c|}{ Basis for ranking tolerance } & \multirow[b]{3}{*}{ SPAD-502 } \\
\hline & Chlorosis & Active & Chlorophyll & \\
\hline & ratings & $\mathrm{Fe}$ & content & \\
\hline Texas sour orange & 2 & 1 & 1 & 1 \\
\hline \multicolumn{5}{|l|}{ Smooth Seville $x$} \\
\hline Argentine trifoliate & 2 & 2 & 2 & 2 \\
\hline F-81-12 citrange & 2 & 2 & 2 & 2 \\
\hline Cleopatra mandarin & 2 & 2 & 4 & 4 \\
\hline Vangasay lemon & 2 & 3 & 2 & 3 \\
\hline \multicolumn{5}{|l|}{ Ridge pineapple $x$} \\
\hline Milam (1578-201) & 2 & 3 & 2 & 3 \\
\hline Troyer citrange & 2 & 3 & 2 & 3 \\
\hline Benton citrange & 2 & 3 & 2 & 4 \\
\hline \multicolumn{5}{|l|}{ Rangpur lime $x$} \\
\hline Swingle trifoliate & 2 & 4 & 4 & 4 \\
\hline \multicolumn{5}{|l|}{ Smooth Seville x } \\
\hline Swingle trifoliate & 2 & 4 & 4 & 4 \\
\hline F-80-3 citrumelo & 3 & 3 & 4 & 4 \\
\hline F-80-5 citrumelo & 4 & 4 & 5 & 4 \\
\hline \multicolumn{5}{|l|}{ Cleopatra mandarin $\mathrm{x}$} \\
\hline Flying Dragon trifoliate & 4 & 5 & 4 & 4 \\
\hline \multicolumn{5}{|l|}{ Sunki mandarin $x$} \\
\hline Benecke trifoliate & 4 & 4 & 4 & 4 \\
\hline \multicolumn{5}{|l|}{ Trifoliate $x$} \\
\hline Ridge pineapple (1573-26) & 4 & 5 & 4 & 4 \\
\hline F-80-8 citrumelo & 5 & 5 & 4 & 4 \\
\hline F-80-18 citrumelo & 5 & 5 & 5 & 5 \\
\hline Flying Dragon trifoliate & 5 & 5 & 5 & 5 \\
\hline
\end{tabular}

${ }^{2}$ Tolerance grouping, 1 = tolerant, as Texas sour orange; 2 = moderately tolerant; $3=$ moderately susceptible, as Troyer citrange; $4=$ susceptible; and $5=$ very susceptible, as Flying Dragon trifoliate,

darin is not known. Given the ease of taking SPAD readings and its high correlation with active Fe and chlorophyll (Table 3), SPAD could be used in place of chlorophyll and active-Fe measurements.

The relative tolerance of Texas sour orange, Cleopatra mandarin, Vangasay lemon, Troyer citrange, Benton citrange, and Flying Dragon trifoliate (Table 5) agreed with previous reports (Wutscher, 1979). Susceptible and very susceptible rootstock include F-80-5, Cleopatra mandarin x Flying Dragon trifoliate, Sunki mandarin $x$ Benecke trifoliate (157326), F-80-8, F-80-18, and Flying Dragon trifoliate. The other trifoliate hybrids were moderately susceptible to bicarbonate-induced chlorosis except for two (Smooth Seville x Argentine trifoliate and F-81-12), which appeared moderately tolerant. No rootstock was as tolerant to bicarbonate-induced chlorosis as Texas sour orange (Table 5).

This study indicated that total leaf Fe concentration is not a good indicator of chlorosis and that SPAD-502 readings can be used instead of leaf active $\mathrm{Fe}$ and leaf chlorophyll concentration as measurements of leaf chlorosis. The tolerance to bicarbonate-induced chlorosis among the trifoliate hybrids tested ranged from very susceptible to moderately tolerant. The two most tolerant lines, Smooth Seville $\mathrm{x}$ Argentine trifoliate and F-81-12 citrange, may
Coulombe, B. A., R.L. Chancy, and W.J. Weibold. 1984. Use of bicarbonate in screening soybeans for resistance to iron chlorosis. J. Plant Nutr. 7:411-425

Davis, R.M. 1986. Virus free varieties from Texas A\&I Center. Calif. Citrograph 7: 181-182.

Dragonuk, M. B., W.R. Fehr, and H.J. Jessen, 1989. Nutrient-solution techniques for evaluation of iron efficiency of soybean. J. Plant Nutr. 12:871880.

Gallaher, R. N., C.O. Weldon, and J.G. Futral. 1975 An aluminum block digester for plant and soil analysis. Soil Sci. Soc. Amer. Proc. 39:803806.

Hamze, M. and M. Nimah. 1982, Iron content during lime-induced chlorosis with two citrus rootstock. J. Plant Nutr. 5 :797-804.

Hamze, M., J. Ryan, and M. Zaabout. 1986. Screening of citrus rootstock for lime-induced chlorosis tolerance. J. Plant Nutr. 9:459-469.

Hiscox, J.D. and G.F. Israelstam. 1979. A method for the extraction of chlorophyll from tissue without maceration. Can. J. Bet. 57: 1332-1 334.

Hoagland, D.R. and D.I. Arnon. 1938. The waterculture method for growing plants without soil. Agr. Expt. Sta. California, Berkely, Circ. 347.

Katyal, J.C. and B.D. Sharma. 1980. A new technique of plant analysis to resolve iron chlorosis. Plant \& Soil 55: 105-1 19,

Marquard, R.D. and J.L. Tipton. 1987. Relationship between extractable chlorophyll and an in situ method to estimate leaf greenness. HortScience 22:1327.

Maxwell, N.P. and H.K. Wutscher. 1976. Yield, fmit size, and chlorosis of grapefruit on 10 rootstock. HortScience 11:496498.

Pierson, E.E. and R.B. Clark. 1984. Ferrous iron determination in plant tissue. J. Plant Nutr. 7:107116.

Rae, J. K., K.L. Sahrawat, and J.R. Burford. 1987. Diagnosis of iron deficiency in ground nut, Arachis hypogaea L. Plant \& Soil 97:353-359.

Rashid, A., G.A. Couvillon, and J.B. Jones. 1990 Assessment of $\mathrm{Fe}$ status of peach rootstock by techniques used to distinguish chlorotic leaves. J. Plant Nutr. 13:285-307.

Abadia, J., J.N. Nishio, E. Monge, L. Montanes, and L. Heras. 1985. Mineral composition of peach leaves affected by iron chlorosis. J. Plant Nutr. 8:697-707.

Bruinsma, J. 1963. The quantitative analysis of chlorophylls a and b in plant extracts. Photochem. Photobiol. 2:241-249.

Byrne, D.H. 1988. Comparative growth of two peach seedling rootstock under alkaline soil conditions. J. Plant Nutr, 11: 1663-1 669.

Campbell, R.J., K.N. Mobley, R.P. Marini, and D.G. Pfeiffer. 1990, Growing conditions alter the relationship between SPAD-501 values and apple leaf chlorophyll. HortScience 25:330-331.

Chancy, R.L. 1984. Diagnostic practices to identify iron deficiency in higher plants. J. Plant Nutr. 7:47-67.

Chancy, R.L., P.F. Bell, and B.A. Coulumbe. 1989. Screening strategies for improved nutrient uptake and use by plants. HortScience 24:565572.

Cooper, W.C. and A. Peynado. 1954. Screening citrus rootstock seedlings for tolerance to calcareous soils. J. Rio Grande Valley Hort. Soc. 8:100-105.
Rouse, R.E., H.W. Browning, C.R. Bogle, and C.C. Connolly. 1986. Rebuilding the citrus industry in Texas. Texas Agr. Expt. Sta. MP-1596.

Singha, S. and E.C. Townsend. 1989. Relationship between chromaticity values and chlorophyll concentrations in apple, grape, and peach leaves. HortScience 24:1035.

Smith, M.W. and J.B. Storey. 1976. The influence of washing procedures on surface removal and leaching of certain elements from pecan leaflets. HortScience 11:50-52.

Takkar, P.N. and N.P. Kaur. 1984. HCl method for $\mathrm{Fe}^{2+}$ estimation to resolve iron chlorosis in plants. J. Plant Nutr. 7:81-90.

Vose, P.B. 1982. Iron nutrition in plants: A world overview. J. Plant Nutr. 5:233-249.

Wallace, A. and O.R. Lunt. 1960. Iron chlorosis in horticultural plants. Proc. Amer. Soc. Hort. Sci. 75:819-841.

Wutscher, H.K. 1979. Citrus rootstock. Hort. Rev. 1:237-269.

Yadava, U.L. 1986. A rapid and nondestructive method to determine chlorophyll in intact leaves. HortScience 21:1449-1450. 